\title{
Analisis Kemampuan Berpikir Kritis Siswa Pada Pembelajaran Tematik Di Kelas Tinggi Sekolah Dasar
}

\author{
Isma Oktavia Nur Alami ${ }^{*}$, Astri Sutisnawati ${ }^{2}$, Din Azwar Uswatun ${ }^{3}$ \\ 1 Universitas Muhammadiyah Sukabumi, Indonesia \\ 2 Universitas Muhammadiyah Sukabumi, Indonesia \\ ${ }^{3}$ Universitas Muhammadiyah Sukabumi, Indonesia \\ *Corresponding author: isma283@ummi.ac.id
}

\begin{abstract}
Critical thinking skills are higher order thinking skills in solving problems rationally. Critical thinking skills have 4 stages in solving problems, namely clarification, assessment, inference and strategy. The clarification stage is the stage where students can state the problem and analyze the meaning of the problem, at this stage students can find the information that is known in the matter correctly. The purpose of implementing the 2013 Curriculum in Indonesia includes developing higher-order thinking skills. This has been explained in the Appendix to Permendikbud Number 21 of 2016 Thematic Learning, namely learning that connects a concept in several different fields of study with the hope that students will learn better and meaningfully. This research method uses qualitative methods. The research population is class V at SDN Tegal Pari, so it can be concluded that students' critical thinking skills in thematic learning in elementary schools are very interconnected during learning activities. The purpose of this study is to describe students' critical thinking skills in thematic learning in high grade elementary schools using qualitative methods in order to know students' critical thinking skills.

Keywords: critical thinking ability; thematic learning
\end{abstract}

\section{ABSTRAK}

Kemampuan berpikir kritis adalah kemampuan berpikir tingkat tinggi dalam memecahkan masalah secara rasional. Kemampuan berpikir kritis memiliki 4 tahap dalam memecahkan masalah, yaitu klarifikasi, assesmen, inferensi, dan strategi. Tahap klarifikasi yaitu tahap dimana siswa dapat menyatakan masalah dan menganalisis pengertian masalah, pada tahap ini siswa dapat menemukan informasi yang diketahui dalam soal secara tepat, Tujuan diberlakukannya Kurikulum 2013 di Indonesia diantaranya, mengembangkan keterampilan berpikir tingkat tinggi . Hal ini telah dijelaskan dalam Lampiran Permendikbud Nomor 21 Tahun 2016 Pembelajaran Tematik yaitu pembelajaran yang menghubungkan suatu konsep dalam beberapa bidang studi yang berbeda dengan harapan siswa akan belajar lebih baik dan bermakna. Metode penelitian ini menggunakan metode kualitatif populasi penelitian adalah kelas V SDN Tegal Pari maka dapat disimpulkan bahwa siswa masih kurang mampu untuk berpikir kritis sebab setiap anak mempunai kemampuan yang berbeda.

Kata Kunci: kemampuan berpikir kritis; pembelajaran tematik

\section{Pendahuluan}

Kemampuan berpikir kritis adalah kemampuan berpikir tingkat tinggi dalam memecahkan suatu masalah secara rasional. Kemampuan berpikir kritis memiliki 4 tahap dalam memecahkan masalah, yaitu tahap klarifikasi, tahap assesmen, inferensi ${ }_{\lrcorner}$dan strategi. Tahap klarifikasi yaitu tahap dimana siswa dapat menyatakan masalah dan menganalisis pengertian dari masalah, pada tahap ini siswa dapat menemukan informasi yang diketahui dalam soal secara tepat. Tahap assesmen yaitu tahap siswa dalam mengajukan informasi yang relevan dan menentukan kriteria penilaian, pada tahap ini siswa dapat merumuskan pertanyaan yang diminta dari soal. Tahap inferen atau penyimpulan yaitu tahap dimana siswa dapat membuat kesimpulan dan menegeralisasi, pada tahap ini siswa dapat menentukan ide/konsep yang akan digunakan dalam menyelesaikan soal. Tahap strategi yaitu tahap 
dimana siswa dapat mengambil tindakan dan menjelaskan tindakan, pada tahap ini siswa dapat menjelaskan langkah-langkah penyelesaian soal yang sudah ditemukan dengan tepat (Faiz, 2012; Suparno Irianto, 2014; Tuanakotta, 2011; Jacob and Sam, 2008)Secara umum tingkat kemampuan berpikir kritis siswa masih tergolong rendah, hal ini dikarenakan penerapan model pembelajaran yang digunakan Secara umum tingkat kemampuan berpikir kritis siswa masih tergolong rendah, hal ini dikarenakan penerapan model pembelajaran yang digunakan. Berpikir kritis merupakan proses berpikir intelektual di mana pemikir dengan sengaja menilai kualitas pemikirannya, pemikir menggunakan pemikiran yang reflektif, independen, jernih, dan rasional.

Keterampilan berpikir kritis adalah proses kognitif siswa dalam menganalisis secara sistematis dan spesifik masalah yang dihadapi, membedakan masalah tersebut secara cermat dan teliti, serta mengidentifikasi dan mengkaji informasi guna merencanakan strategi pemecahan masalah. Pendapat tersebut diperkuat oleh Stobaugh (2013: 2) yang menjelaskankan bahwa berpikir kritis adalah berpikir yang reflektif secara mendalam dalam pengambilan keputusan dan pemecahan masalah untuk menganalisis situasi, mengevaluasi argumen, dan menarik kesimpulan yang tepat. Di dalam pelaksanaan kurikulum 2013, guru memiliki peran yang cukup vital, baik dalam peran untuk merencanakan, melaksanakan, atau untuk menilai. Artinya di dalam proses implementasi kurikulum 2013, guru menjadi seorang planner, eksekutor, dan developer kurikulum dalam setiap sekolah di Indonesia. Dengan demikian, di dalam implementasi kurikulum 2013, setiap guru dituntut untuk menguasi pemahaman maknad dalam setiap bidang studi, pengetahuan terkait karakter peserta didik, melaksanakan sebuah praktik peran sebagai suatu pembelajaran yang edukatif dan menyenangkan, serta harus memiliki potensi untuk mengembangkan sikap profesionalisme dan kepribadian (Mulyasa, 2014).

Pembelajaran tematik telah menjadi salah satu strategi efektif untuk pembelajaran kontekstual yang terkait dengan pengalaman sehari-hari siswa (Yuh-Tyng Chen, 2012). Menurut (Liu \& Wang, 2010) pembelajaran tematik dapat memadukan pengetahuan siswa dalam konsep dan menyediakan kerangka untuk membangun konsep-konsep yang ada. Pembelajaran tematik yang terintegrasi membuat belajar dan mengajar menjadi sangat menyenangkan bagi guru dan anak-anak. Memberi kesempatan yang luas kepada anak untuk mengekspresikan diri mereka sesuai dengan usia (Varun, 2016), (John, 2015). Pembelajaran tematik juga dapat meningkatkan berpikir ilmiah dan kerja ilmiah siswa (Mudiono, Gipayana, \& Madyono, 2016). Membantu siswa mengembangkan keterampilan utama di seluruh disiplin ilmu (John, Joseph, \& Sampson, 2014).

Mengingat pentingnya pembelajaran yang terintegrasi dan pengembangan keterampilan berpikir tingkat tinggi sangat dibutuhkan dengan meningkatnya global kompetisi. (Davies \& Brown, 2011) menyatakan pentingnya mempersiapkan generasi pendidik untuk mengembangkan kompetensi guru diperencanaan dan implementasi pembelajaran tematik. kegiatan pembelajaran yang dimuat dalam silabus hanyalah kegiatan pokok untuk setiap pembelajaran. Pembelajaran tematik menggunakan tema yang sudah disediakan oleh pemerintah pusat. Tema disesuaikan dengan buku guru dan kurikulum sekolah yang mengacu pada kurikulum nasional. Dalam perencanaan pembelajaran tematik guru tidak lagi menentukan tema. Tema yang digunakan dalam buku pegangan peserta didik yakni BUPENA adalah yang dalam lingkungan hidup peserta didik. Tema yang dibuat sesuai 
dengan minat, kebutuhan, lingkungan, dan pengalaman belajar siswa. (Hakim, 2009) mengatakan bahwa pembelajaran tematik merupakan suatu model dan strategi pembelajaran yang mengintegrasikan berbagai mata pelajaran melalui area isi, keterampilan, dan sikap ke dalam suatu tema tertentu untuk memperoleh pengalaman belajar yang menarik dan optimal. Beberapa judul tema yang diangkat dalam pembelajaran tematik masalah yang disajikan dalam tema dapat ditemui oleh siswa dalam lingkungan sekolah maupun masyarakat. Berdasarkan beberapa pengertian pembelajaran tematik bahwasannya pembelajaran tematik yaitu suatu pembelajaran yang mengintegritaskan suatu materi dari beberapa mata pembelajaran menjadi suatu tema tau topik pembelajaran sehingga siswa akan belajar akan menjadi lebih baik dan lebih bermakna.

\section{Metode Penelitian}

Jenis penelitian ini yaitu menggunakan metode penelitian deskriptif kualitatif, yaitu mengumpulkan data berupa kata-kata dan gambar dari pada angka-angka. Penelitian deskriptif adalah penelitian yang dilakukan dibawah kondisi alam dilingkungan alami, dan penulis menyesuaikan penelitian ini dengan kondisi alami, terutama saat ini. Dalam penelitian ini, penulis menggunakan metode kualitatif. Menurut metode kualitatif yang dikemukakan oleh Mantra (2004) dalam Siyoto \& Sodik (2015: 27), sebagai program penelitian menghasilkan data deskriptif dan perilaku yang dapat diamati dalam bentuk kata-kata atau kata-kata. Metode kualitatif bertujuan untuk mengungkap keunikan individu, kelompok, masyarakat dan/atau organisasi dalam kehidupan sehari-hari secara rinci dan mendalam, serta dapat dijelaskan secara ilmiah. Menurut teori yang telah dipaparkan, dapat disimpulkan bahwa penelitian deskriptif kualitatif adalah penyelidikan yang dilakukan untuk menggambarkan setiap peristiwa yang dialami siswa dalam kondisi alam, terutama peristiwa yang dialami selama kegiatan pembelajaran.

Penelitian ini di laksakan di SDN Tegal Pari Jl. Gotong Royong RT/RW 014/005 kelurahan Gunung Puyuh kecamtan Gunung Puyuh Kota Sukabumi pengambilan data di lakukan pada tanggal 24 Desember 2020 pada semester 1 tahun ajaran 2020/2021 melalui wawancara wali kelas. Subjek penelitian ini adalah guru dan siswa kelas 5 SDN Tegal Pari dengan memilih seluruh siswa di dalam kelas dengan jumlah 26 orang dan jumlah laki-laki ada 12 orang dan jumlah perempuan 14 orang siswa. Teknik pengumpulan data menggunakan teknik tringulasi dalam teknik pengumpulan data, tringulasi diartikan sebagai teknik pengumpulan data yang bersifat menggabungkan dari berbagai teknik pengumpulan data dan sumber data yang telah ada.

\section{Hasil dan Pembahasan}

Selain menggunakan teknologi wawancara guru, peneliti juga menggunakan teknologi angket kemudian dibagikan kepada siswa melalui pertanyaan essay karena sangat penting digunakan agar mampu mengetahui kemampuan siswa karena untuk mengembangkann keterampilan berpikir kritis siswa. Data yang dihasilkan dari angket dengan menggunakan soal essay yang sudah disebarkan kepada siswa kelas 5 SDN Tegal Pari. Jumlah pernyataan yang terdapat pada angket tersebut berjumlah 10 butir soal dengan kategori penilaianya itu terdapat empat kategori seperti sangat baik (4) baik (3), cukup (2) dan kurang baik (1). 
Berdasarkan hasil dari angket yang sudah disebar siswa yang telah mengisi soal sebanyak 26 orang siswa , hal itu menjelaskan bahwa seluruh siswa kela 5 SDN Tegal Pari sudah mengisi angket yang yang sudah disebar.

Berdasarkan dari hasil data hasil yang sudah disebarkan melalui whatsapp grup dapat dihasilkan bahwa tidak semua siswa mampu berpikir kritis saat kegiatan pembelajaran berlangsung. Karena setiap kemampuan siswa berbeda-beda. Contoh dalam pembelajaran dimana siswa diminta untuk memberikan suatu argument atau alasan terhadap materi yang sudah diajarkan oleh guru kelas, siswa masi kurang untuk bisa memberikan satu argument atau alasan yang tepat. Dan masi ada juga siswa yang masi kurang mampu dalam menyimpulkan suatu materi atau suatu pembahasan dimana pembahasan tersebut sudah dijelaskan oleh guru kelas kepada siswa. Dilihat juga dari hasil uraian yang disebarkan kepada siswa bahwa nilai yang didapat dari indicator yaitu siswa mendapatkan nilai yang berada pada nilai 50-85, akan tetapi nilai paling banyak yaitu ada pada nilai 50-70 sehingga mendapatkan kategori kurang baik. Dengan demikian hasil tersebut menunjukan bahwa siswa menggunakan waktunya dalam penyelesain mengerjakan tugas sudah termasuk kurang efektiff. Beberapa siswa dalam mengerjakan tugas kurang tepat dalam mengisi jawaban soalnya. Dan berdasarkan nilai yang didapat 80-85 yang didapat hanya Sebagian dari siswa saja.

Tabel 1. Nilai Siswa

\begin{tabular}{rcc}
\hline Nilai & Banyak Siswa & Jumlah Nilai \\
\hline 50 & 5 & 250 \\
53 & 3 & 159 \\
55 & 2 & 110 \\
58 & 1 & 581 \\
60 & 2 & 120 \\
62 & 3 & 186 \\
63 & 2 & 126 \\
65 & 2 & 130 \\
70 & 2 & 140 \\
75 & 1 & 75 \\
80 & 2 & 160 \\
85 & 1 & 170 \\
Jumlah & & $\mathbf{1 . 6 8 4}$ \\
\hline
\end{tabular}

Berdasarkan uraian yang telah disebarkan oleh guru kelas kepada keseluruh siswa kelas 5 dengan total 26 siswa, dengan KKM pembelajaran IPA yaitu 70 dapat dilihat dari table di atas yaitu siswa dengan jumlah nilai rata-rata 64 bahwasannya siswa masi kurang untuk mencakup KKM pembelajaran IPA sedangkan untuk $\mathrm{kkm}$ itu sendiri guru kelas telah menetapkan bahwa KKM pembelajaran IPA yaitu 70, Sebagian siswa sudah cukup mampu untuk hal menyimpulkan akan tetapi siswa masi kurang mampu dalam memberikan suatu argument dimana siswa diminta untuk memberikan jawaban disertai alasan saat kegiatan pembelajaran berlangsung ataupun di saaat kegiatan ujian baik itu tulisan maupun lisan.

Menurut Ahmad dalam (Mukarromah, 2018:121) berpikir kritis adalah sesuatu yang terhubung dengan konsep yang diberikan dengan suatu masalah yang dipaparkan dengan 
berpikir kritis tersebut maka dari itu siswa akan memiliki kemampuan berpikir kritis secara mendalam tentang masalah dan hal yang berada pada jangkauan pengalaman pada seseorang alternatif yang dapat digunakan untuk pemecahan masalah tersebut dalam rangka meningkatkan berpikir kritis dan hasil belajar siswa adalah dengan penggunaan model pembelajaran yang dapat melibatkan siswa untuk berpikir kritis dan terlibat langsung secara aktif dalam kegiatan pembelajaran. Browne dan Keeley dalam (Mukarromah, 2018:3) berpendapat bahwa berpikir kritis mencakup pemahaman pertanyaan kritis yang saling terkait, serta kemampuan dan kemauan untuk bertanya dan menjawab pertanyaan pada waktu yang tepat. Pengertian dari kedua ahli tersebut menunjukkan bahwa berpikir kritis dapat dilakukan sesuai kebutuhan, karena berpikir kritis terdiri dari sekumpulan pertanyaan, dan kemampuan serta kemauan untuk bertanya dan menjawab pertanyaan dengan benar merupakan salah satu ciri dari keterampilan berpikir kritis.

Kemampuan berpikir kritis setiap siswa berbeda-beda, tergantung pada latihan yang sering dilakukan untuk mengembangkan berpikir kritis. Kenyataan yang ditemui di sekolah, menunjukkan bahwa dalam mempelajari IPA mereka masih teoritis dan kurang mengembangkan kemampuan berpikir kritis. Keantusiasan siswa dalam menjawab pertanyaan yang diajukan guru masih terbatas secara teori belum menunjukkan pengembangan yang sesuai dengan potensi serta kemampuan mereka. Karena siswa tidak dapat menggunakan keterampilan berpikir kritis dalam belajar mengajar, siswa hanya menerima penjelasan guru, mencatat dan mendengarkan, dan tidak menyajikan argumen atau pertanyaan. Oleh karena itu, keterampilan berpikir kritis yang dibutuhkan dalam kurikulum 2013 tidak cukup melukiskan gambaran. Hal ini terlihat ketika guru menjelaskan materi pembelajaran atau siswa menyelesaikan pertanyaan yang diajukan oleh guru. Pelaksanaan pembelajaran tidak memberikan gambaran bahwa siswa berpusat pada siswa, sehingga guru hanya menggunakan satu varian pengajaran tanpa memperhatikan siswa agar dapat berpikir kritis.

Kemampuan berpikir kritis perlu dikembangkan kepada setiap siswa. Pentingnya berpikir kritis untuk setiap siswa yaitu agar siswa dapat memecahkan segala permasalahan yang ada di dalam dunia nyata. Berpikir kritis adalah kemampuan seseorang dalam mendapatkan informasi dan pemecahan dari suatu masalah dengan cara bertanya kepada dirinya sendiri untuk menggali informasi tentang masalah yang sedang dihadapi Christina \& Kristin dalam (Saputro et al., 2019:622) menjelaskan bahwasannya hal tersebut disebabkan karena dalam proses pembelajaran, siswa akan mempertanyakan berbagai informasi yang diterima dan menggunakan kemampuan berpikirnya untuk menganalisis dan mengevaluasi permasalahan tersebut dengan menggunakan alasan yang logis.Berdasarkan pembahasan diatas, keterampilan berpikir kritis yaitu merupakan suatu kemampuan dasar untuk memecahkan masalah. Maka dari siswa diminta untuk mampu berpikir kritis dalam memberikan argument yang didasari dengan alasan pada saat kegiatan pembelajran atau kegiatan lainnya.

Harlinda (2014: 6) Mendefinisikan berpikir adalah upaya yang menggunakan daya nalar untuk mengolah informasi dari luar dan dalam untuk memecahkan masalah. Dapat disimpulkan bahwa berpikir adalah proses yang melibatkan interaksi kompleks antara atribut mental seperti penilaian, abstraksi, penalaran, dan imajinasi, dalam upaya memecahkan masalah yang tidak dapat diamati melalui proses fisik. 
Berpikir kritis dan kreatif merupakan kemampuan yang harus dimiliki setiap orang, termasuk siswa sekolah dasar Wahyudi dan Waluya dalam (Lisbiyaningrum et al., 2019:162). Akibatnya semua negara, terutama Indonesia, harus meningkatkan kualitas pendidikan., Terutama pembelajaran yang memberikan kesempatan kepada siswa untuk dapat memberikan kesimpulan agar mampu untuk berpikir kritis dan kreatif Syafarudin dan Wahyudi dalam (Lisbiyaningrum et al., 2019:162) menyatakan Dengan dukungan sumber daya manusia yang berkualitas, kualitas pendidikan dapat ditingkatkan pembelajaran di sekolah diharapkan juga melatih siswa untuk berpikir kritis. Membelajarkan berpikir kritis penting karena melalui berpikir kritis, siswa akan dilatih untuk mengamati keadaan, memunculkan pertanyaan, merumuskan hipotesis, melakukan observasi dan mengumpulkan data, lalu memberikan kesimpulan. Berpikir kritis juga melatih siswa untuk berpikir. Saat kegiatan pembelajaran berlangsung. Akan tetapi siswa tidak semua siswa akan mampu untuk menyimpulkan suatu pembelajaran dikelas Dan Pembelajaran tematik adalah pembelajaran yang menggunakan tema dalam mengaitkan beberapa mata pelajaran sehingga dapat memberikan pengalaman bermakna kepada siswa. Sehingga siswa mampu untuk berperan aktif saat kegitanan pembelajaran berlangsung dimana siswa dituntut untuk lebih aktif dan kreatif sehingga siswa dapat menyimpulkan suatu pembelajara yang sudah dijelaskan oleh guru atau pun siswa sehingga kita dapat melihat siswa tersebut apakah sudah mampu atau belum dalam menyimpulkan suatu pembelajaran. Tema adalah pokok pikiran atau gagasan pokok yang menjadi pokok pembicaraan. Pembelajaran tematik lebih menekankan pada keterlibatan siswa dalam proses belajar secara aktif dalam proses pembelajaran, sehingga siswa dapat memperoleh pengalaman langsung dan terlatih untuk dapat menemukan sendiri berbagai pengetahuan yang dipelajarinya. Melalui pengalaman langsung siswa akan memahami konsep-konsep yang mereka pelajari dan menghubungkannya dengan konsep lain yang telah dipahaminya. Teori pembelajaran ini dimotori para tokoh Psikologi Gestalt, termasuk Piaget yang menekankan bahwa pembelajaran haruslah bermakna dan berorientasi pada kebutuhan dan perkembangan anak.

Berdasarkan hasil wawancara mengemukakan bahwa siswa belum dapat dikatakan mampu untuk merumuskan suatu masalah atau memberikan argument saat kegiaatn pembelajaran berlangsung dikarenakan kemampuan siswa sekolah dasar berbeda dengan tingkatan sekolah menengah atas atau menengah akhir bahkan tingkatan yang selanjutnya. Karna tingkatan kemampuan anak sekolah dasar masi dikatakan masi kurang mampu akan tetapi bisa dikatakana sudah mampu juika siswa tersebut berasda pada tingkatan yang sama yaitu tingkatan siswa sekolah dasar. Cara guru agar mengetahui siswa tersebut sudah mampu untuk berpikir kritis adalah dengan cara melontarkan suatu pertanyaan yang berbentuk dengan tulisan maupun lisan, bukan hanya dalam segi pembelajaran nya saja siswa mampu di katakana berpikir keritis akan teapi dalam kehidupan sehari-hari pun dapat menilai siswa tersebut sudah mampukah untuk berpikir kritis.

Brookfiel dalam (Mukarromah, 2018:14) menjelaskan bahwa pemikiran kritis sebagai kebiasaan untuk memastikan bahwa asumsi kita akurat dan tindakan kita akan menghasilkan hasil yang kita inginkan sedangkan menurut Daryanto \& Karim dalam (Mukarromah, 2018:21) berpikir keritis adalah dimna kita bisa membedakan yang asumsi dan yang akurat walaupun siswa tersebut masi dibangku sekolah dasar akan Kemampuan berpikir kritis merupakan salah satu kemampuan berpikir tingkat tinggi yang harus dimiliki siswa dan sejalan dengan 
tujuan kurikulum 2013, yaitu menumbuhkan kemampuan berpikir kritis siswa. Permendikbud No 103 menjelaskan bahwa salah satu ciri mata kuliah 2013 adalah pendekatan saintifik dan tematik yang terintegrasi, yang meliputi kegiatan observasi, inkuiri, kompilasi, dan penalaran Daryanto \& Karim dalam (Mukarromah, 2018:1). Kemampuan berpikir kritis adalah salah satunya. Siswa harus memiliki keterampilan berpikir tingkat tinggi untuk memenuhi tujuan kurikulum 2013, yaitu memungkinkan siswa untuk berpikir kritis. Permendikbud No. 103 menjelaskan bahwa salah satu ciri kurikulum 2013 adalah pendekatan saintifik dan tematik yang terintegrasi, yang meliputi kegiatan observasi, inkuiri, pengumpulan, menalar dan komunikasi. Untuk menjawab tantangan tersebut, diperlukan model pembelajaran yang mendukung untuk meningkatkan kemampuan berpikir kritis siswa.

Cara agar mengetahui siswa mampu memutuskan suatu masalah atau suatu Tindakan contohnya dalam kegiatan praktik yaitu dengan cara pengamatan yang sedang berlangsung agar kita bisa mengetahui anak tersebut sudah mampu atau belum dalam memutuskan suatu Tindakan dengan cara kegiatan praktik contohnya dalam kegiatan praktik pada materi yang sedang berlangsung ataupun pembelajaran lainnya. Tidak semua siswa yang mampu berpendapat mengenai suatu materi pembelajaran berlangsung dikarenakan sebagi siswa yang tidak memahami atau kurang memerhatikan pembelajarn yang sedang guru jelaskan ada juga sebagian siswa saat ditanya apaah ada pertanyaan? Kebanyakan siswa hanya berdiam atau pura-mengerti akan penjelasan yang sudah guru jelaskan di dalam kelas. Akan tetapi siswa dapat memutuskan suatu masalah atau suatu kegiatan apapun dengan pengelompokan bermain dimana siswa pasti sudah mampu untuk memutuskan suatu masalah. Berbeda dengan memutuskan suatu kegiatan pembelajaran tidak semua siswa akan mampu memutuskan suatu Tindakan atau memutuskan suatu pembeajaran yang sesang berlangsung.

\section{Kemampuan Berpikir Kritis}

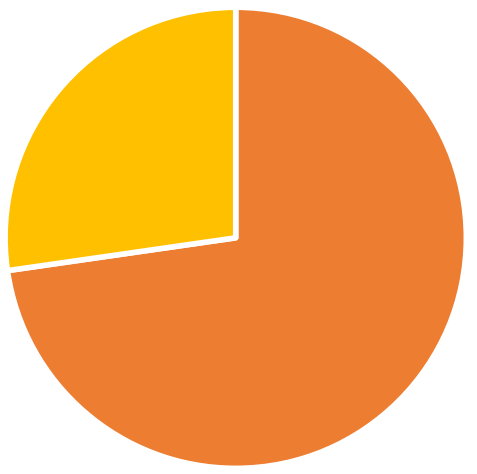

- Siswa masi kurang dalam Berfikir Kritis - " Sudah mampu dalam Berfikir Kritis

Gambar 1. Grafik Presentasi Kemampuan Berpikir Kritis Siswa

Gambar 1 menunjukan bahwa kemampuan Berpikir Kritis Siswa pada pembelajaran Tematik di Sekolah Dasar masih rendah. Berdasarkan wawancara diatas bahwasannya siswa masi kurang mampu untuk berpikir kritis dalah hal merumuskan masalah, memberikan argument atau jawaban yang disertai dengan alasan dan siswa juga masi kurang mampu dalam menyimpulkan saat materi pembelajaran. Tujuannya yaitu agar berpikir kritis dapat 
membuat orang tertarik pada pendapat dan percaya bahwa hal-hal tertentu ada karena alasan logis. Berpikir kritis pada dasarnya adalah kemampuan untuk menanamkan sikap mandiri, disiplin, dan mengendalikan serta mengoreksi kesalahan sendiri. Berdasarkan sudut pandang di atas, dapat disimpulkan bahwa tujuan berpikir kritis adalah mempersiapkan siswa untuk mendorong seseorang menjadi pemikir kritis agar dapat mengajukan pertanyaan, mengumpulkan informasi, mengajukan pertanyaan dan memelihara pikiran terbuka untuk mencapai tujuan yang efektif dan efisien. hasil yang efisien. komunikasi yang efisien. Ini membawa banyak manfaat. Untuk diri sendiri atau untuk orang lain.

\section{Kesimpulan}

Berdasarkan hasil penelitian maka dapat disimpulkan siswa masih kurang mampu untuk berpikir kritis sebab setiap anak mempunai kemampuan yang berbeda. Siswa sekolah dasar tidak bisa di katakan mampu untuk berpikir kritis yang sangat tinggi karena tingkatan kemampuan berpikir siswa sekolah dasar berbeda dengan kemampuan berpikir kritis anak dengan tingkatan sekolah menengah atas maupun tingkatan menegah akhir dan tingkatan lainnya.

\section{Daftar Pustaka}

Ahmatika, D. (2017). Peningkatan Kemampuan Berpikir Kritis Siswa dengan Pendekatan Inquiry/Discovery. Euclid, 3(1), 394-403. https:/ / doi.org/10.33603/e.v3i1.324

Alita, K. U., Koeswanti, H. D., \& Giarti, S. (2019). Penerapan Model Problem Based Learning untuk Meningkatkan Kemampuan Berpikir Kritis Siswa Kelas V SDN Ledok 5 Tahun Pelajaran 2018/2019. Jurnal Basicedu, 3(1), 169-173. https://doi.org/10.31004/basicedu.v3i1.97

AM, I. A., Saputra, S. Y., \& Amelia, D. J. (2018). Pembelajaran Tematik Integratif Pada Kurikulum 2013 di Kelas Rendah SD Muhammadiyah 07 Wajak. JINoP (Jurnal Inovasi Pembelajaran), 4(1), 35. https:// doi.org/10.22219/jinop.v4i1.4936

Anugraheni, I. (2018). Meta Analisis Model Pembelajaran Problem Based Learning dalam Meningkatkan Keterampilan Berpikir Kritis di Sekolah Dasar. Polyglot, 14(1), 9-18. http://dx.doi.org/10.19166/pji.v14i1.789

Arifin. (2018). Meningkatkan Kemampuan Berpikir Kritis Peserta Didik Menggunakan Model Problem Based Learning (PBL) di Kelas IV SD. Fkip-1 PGSD, 1(1), 1-8.

Aristini, N. K. D., Sudarma, I. K., \& Riastini, P. N. (2017). Pengembangan Lembar Kerja Siswa Berbasis Inkuiri untuk Pemahaman Konsep IPA Siswa Kelas V. E- Journal PGSD Universitas Pendidikan Ganesha, 5(2), 1-12.

Azizah, M., Sulianto, J., \& Cintang, N. (2018). Analisis Keterampilan Berpikir Kritis Siswa Sekolah Dasar pada Pembelajaran Matematika Kurikulum 2013. Jurnal Penelitian Pendidikan, 35(1), 61-70. https:// doi.org/10.15294/jpp.v35i1.13529

Caitra, Z. D. (2019). Pengembangan Perangkat Pembelajaran Model Think Talk Write Subtema Hidup Rukun Untuk Meningkatkan Kemampuan Berpikir Kritis Siswa Kelas V Sekolah Dasar. Jurnal Review Pendidikan Dasar: Jurnal Kajian Pendidikan Dan Hasil Penelitian, 5(2), 949. https://doi.org/10.26740/jrpd.v5n2.p949-957

Edriati, S., Anggraini, V., \& Siska, M. (2012). Efektivitas model. 288-295. 
Fakhriyah, F. (2014). Penerapan Problem Based Learning dalam Upaya Mengembangkan Kemampuan Berpikir Kritis Mahasiswa. Jurnal Pendidikan IPA Indonesia, 3(1), 95-101. https://doi.org/10.15294/jpii.v3i1.2906

Fay, D. L. (2016). Peningkatan Proses Pembelajaran Tematik Terpadu Menggunakan Contextual Teaching And Learning (CTL) Di Kelas IV Sekolah Dasar. Angewandte Chemie International Edition, 6(11), 951-952., C.

Febrita, I., \& Harni. (2020). Model Problem Based Learning dalam Pembelajaran Tematik Terpadu terhadap Berpikir Kritis Siswa di Kelas IV SD. Jurnal Pendidikan Tambusai, 4(2), 1619-1633.

Fernández, O., Kang, S., Laily Noor Ikhsanto, jurusan teknik mesin, \& Aceh, kue tradisional khas. (2020). Strategi Guru Dalam Mengembangkan Keterampilan Berpikir Kritis (Critical Thinking) pada Pembelajaran Tematik Terpadu Kelas V SEKOLAH DASAR. E- Journal PGSD FKIP Jambi, 2017(1), 1-9.

Hallatu, Y. A. (2017). (Retracted) Pengaruh Model Problem Based Learning terhadap Kompetensi Pengetahuan Dan Keterampilan Berpikir Kritis Siswa Madrasah Aliyah Bpd Iha Tentang Konflik. The Indonesian Journal of Social Studies, 1(1), 11. https://doi.org/10.26740/ijss.v1n1.p11-22

Lisbiyaningrum, I., Wahyudi, \& Wulandari. (2019). Penerapan Problem Based Learning dalam Pembelajaran Tematik Integratif untuk meningkatkan Kemampuan Berpikir Kritis Siswa Kelas III Sekolah Dasar. Elementary School: Jurnal Pendidikan Dan Pembelajaran Ke-SD-An, 6(2), 161-168.

Maisoka. (2019). Struktur Berpikir Kritis Siswa Sekolah Dasar pada Pembelajaran IPA. Studi, Program Guru, Pendidikan Dasar, Sekolah Tamansiswa, Universitas Sarjanawiyata, April, 205210.

Mawardi, M., Wardani, N. S., Hardini, A. T. A., \& Kristin, F. (2019). Model Desain Pembelajaran Tematik Terpadu Kontekstual untuk Meningkatkan Kebermaknaan Belajar Siswa SD. Scholaria: Jurnal Pendidikan Dan Kebudayaan, 9(1), 48-61. https://doi.org/10.24246/j.js.2019.v9.i1.p48-61

Mukarromah, A. (2018). Analisis Kemampuan Berpikir Kritis pada Model Discovery Learning Berdasarkan Pembelajaran Tematik. Indonesian Journal of Primary Education, 2(1), 38. https://doi.org/10.17509/ijpe.v2i1.11844

Nahak, K. E. N., Degeng, I. N. S., \& Widiati, U. (2019). Pembelajaran Tematik di Sekolah Dasar. Jurnal Pendidikan:Teori, Penelitian, Dan Pengembangan, 4(6), 785-794.

Noorhapizah, Akhmad Riyandi Agusta, D. A. P. (2020). Pengembangan Bahan Ajar Bermuatan Keterampilan Berpikir Kritis, Berpikir Kreatif dan Berpikir Logis Berbasis Kearifan Lokal. Skripsi dalam Universitas Lambung Akurat.

Rasyidyah, S., \& Komalasari, M. D. (2019). Efektivitas Model PBL ditinjau dari Kemampuan Berpikir Kritis pada Pembelajaran Tematik. 93-112.

Rokhimawan, M. A., \& Leli, N. (2019). Pengaruh Strategi Point Counter Point terhadap Keterampilan Berbicara Dalam Pembelajaran Tematik. Terampil: Jurnal Pendidikan dan Pembelajaran Dasar, 5(2), 247-257. https://doi.org/10.24042/terampil.v5i2.3119

Samantha, R., \& Almalik, D. (2019). Penerapan Model Pembelajaran Problem Based Learning untuk Meningkatkan Sikap Kerja Sama Dan Hasil Belajar Siswa Pada Pembelajaran Tematik di SDN Kencana Indah II. Tjyybjb.Ac.Cn, 3(2), 58-66. 
http://www.tjyybjb.ac.cn/CN/article/downloadArticleFile.do?attachType=PDF\&id=9 987

Saputro, B., Sulasmono, B. S., \& Widyanti, E. (2019). Peningkatan Kemampuan Berpikir Kritis Dan Hasil Belajar Matematika Menggunakan Model PBL pada Siswa Kelas V. Jurnal Pendidikan Tambusai, 3(2), 621-631. https://www.journal.umtas.ac.id/index.php/naturalistic/article/view/405

Sholehah, L. A. (2017). Perbedaan Kemampuan Kognitif Siswa Menggunakan Model Pembelajaran Kancing Gemerincing Dan Jigsaw Pada Pembelajaran Tematik Tema 9 Kelas V SD. Jurnal Pemikiran Dan Pengembangan Sekolah Dasar (JP2SD), 5(2), 758. https:// doi.org/10.22219/jp2sd.vol5.no2.758-765

Siyoto, S., \& Sodik A. (2015). Dasar Metodologi Penelitian. Yogyakarta: Literasi Media Publishing.

Suherli, T. (2018). Kinerja Mengajar Guru Dalam Mengimplementasi Kurikulum 2013 Sebagai Upaya Pembentukan Karakter di Sekolah Dasar. Indonesian Journal of Education Management and Administration Review, 2(2), 292-299. https://jurnal.unigal.ac.id/index.php/ijemar/article/download/1926/1544

Sulistiani, E., Budiarti, R. S., \& Muswita. (2016). Analisis Kemampuan Berpikir Kritis Siswa Lintas Minat pada Pembelajaran Biologi Kelas X SMAN 11 Jambi. Biodik, 2(1), 13-19. https://online-journal.unja.ac.id/biodik/article/view/3363 